\title{
A Framework for Macro Stress-Testing the Credit Risk of Commercial Banks: The Case of Vietnam
}

\author{
Oanh T. K. Vu ${ }^{1}$, Yen H. Vu ${ }^{1}$, Trang T. T. Nguyen ${ }^{1} \&$ Trung H. Bui ${ }^{1}$ \\ ${ }^{1}$ Banking Faculty, Banking Academy of Vietnam, Hanoi, Vietnam \\ Correspondence: Oanh T. K. Vu, Banking Faculty, Banking Academy of Vietnam, Hanoi, Vietnam. Tel: +8498 \\ 357 1083. E-mail: oanhvtk@hvnh.edu.vn
}

Received: September 12, $2017 \quad$ Accepted: October 2, $2017 \quad$ Online Published: January 29, 2018

doi:10.5539/ass.v14n2p1

URL: https://doi.org/10.5539/ass.v14n2p1

\begin{abstract}
In this paper, we assess the capacity of Vietnamese commercial banks to withstand the effects of an increase in credit risk as a result of macroeconomic shocks. Firstly, VAR model is used to estimate the relationship among macro variables (real GDP, real exchange rate, lending interest rate and inflation rate) and from that, macroeconomic scenarios are set up. Next, we employ a GMM model to estimate the relationship between the non-performing loan ratio (credit risk) and macro variables involved in first step. Finally, the new capital requirement ratio (CAR) is recalculated, which is based on the increase in loan provision followed by the rise in non-performing loan. The results show that credit risk which the commercial banks have to face is relatively limited when their risk weighted assets are unchanged. If these numbers, however, increase as banks broaden their lending, all banks' CAR will reduce remarkably and four large banks will be lack of capital seriously and cannot meet the requirement of Central Bank
\end{abstract}

Keywords: credit risk, NPL, stress test, VAR model

JEL: G21, G28, G32

\section{Introduction}

Stress testing refers to a range of techniques used to assess the vulnerability of a portfolio/bank to "exceptional but plausible" macroeconomic shocks. To assess the vulnerability, according to Basel, the adverse shock used in stress test must be "extreme and exceptional" but "plausible" (Basel, 2009). The impacts of stress test might be shown as financial impacts on capital, loss (solvency stress test), or solvency (liquidity stress test). By conducting stress test periodically, the supervisory body may be able to actively cope with the worst-ever scenarios. Stress testing applies appropriate techniques for credit risk, market risk, liquidity risk and other risks. Credit risk stress testing concentrates on the risk that a borrower is unable to pay debt in certain circumstances.

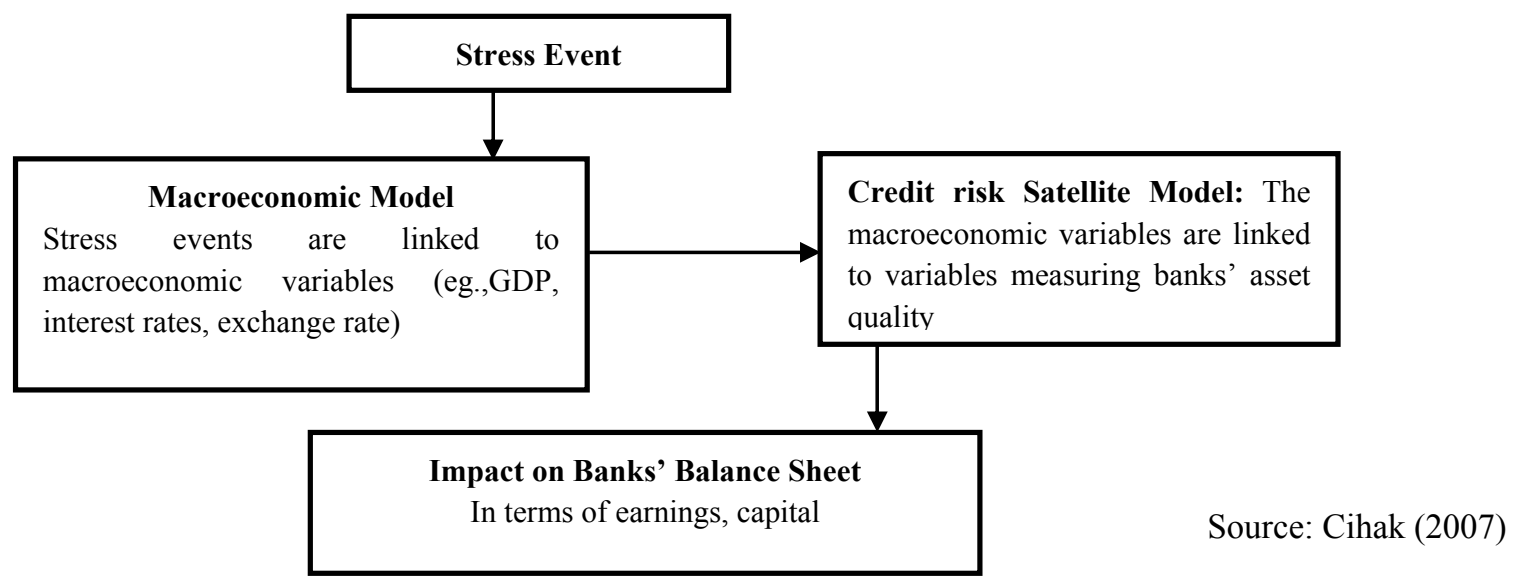

Figure 1. Credit Risk - A Typical Macro Stress Testing Process

The stress testing may be performed by an individual bank, group of banks with some similar characteristics or the system. At the micro level, stress test is designed to assess the sustainability of a financial institution for the 
purpose of risk management, while at the macro level, stress test is applied to test the sustainability of the system. The purpose of macro stress testing is to help the supervisory body define the sensitivity of the system to stressed events which might lead to the system break-down (Basurto, 2006). The macro stress testing, as a result, is mainly realized by Central Banks or international institutions as IMF, WB. The stress testing process involves several stages, as shown in Figure 1.

First step - Identify a stress event from exogenous factors. The stressed events might be a shock affecting to the domestic economy, which is large enough and still possible. The effects of the stressed scenario to macroeconomic conditions are measured by a structural econometric model, vector auto regression method and/or pure statistical approach (Foglia, 2009; Bank of Japan, 2007; Van den End, Hoeberichts \& Tabba, 2006)

Second step - Model the relationship between credit risks and other macroeconomic variables derived in stage 1. The macroeconomic model does not include credit risk measurement; therefore, in the second stage of stress testing, links between credit risk measurement and macroeconomic variables will be modeled by satellite model to assess the effects of endogenous shocks to the bank's asset quality. These models are estimated either for the whole system or for different levels of disaggregation as by industry, type of borrower, such as bank or individual borrowers. The regression models include loan performance variables as non-performing loan (NPL), or loan loss provisions (LLP) as dependent variables, the explanatory variables include a set of macroeconomic variables, bank/industry specific variables as measures of indebtedness... Variables as economic growth, unemployment, interest rate, exchange rate, equity prices... are all explanatory variables, in which, interest rate is a crucial variable as it is the direct cost of borrowing. (Castren, Dees, \& Zaher, 2008; Blaschke, Jones, Majnoni, \& Martinez-Peria, 2001)

Third step (last step) - Assess the impacts on loan portfolio of the bank and assess the capacity of the bank to stand to given stressed events. This means the loss of the bank should be compared to a suitable benchmark.

The results of the simulation might be shown as loan loss provision or predicted default rate, which depends on types of employed credit risk models; or with a known recovery rate, the bank's projected loss might be estimated, loan loss provision is defined.

In the study of Pilinko and Romancenco (2014) in Latvia, the authors calculated the new CAR - CAR in stressed scenario considering the increase in provisions as the bank's bad loans increased in adverse condition. The authors compared the calculated CAR with the requirement of Basel $-8 \%$ to assess the vulnerability of the bank in stressed case.

\section{Stress testing: Empirical implementation in Vietnam}

\subsection{Macroeconomic Scenario Establishment}

\subsubsection{Macroeconomic Variable and Credit Risk}

The effects of macroeconomic variables to credit risk in commercial banks has been widely discussed in many research. Some macroeconomic variables which have great impacts on credit risk are listed in the followings.

Economic growth, usually represented by Gross Domestic Product (GDP), is a basic indicator of the cyclical position of the economy. A rise or high growth in GDP affect credit risk via a positive effect on corporate earnings, wage growth, which, inturn, increase the borrower's capacity to pay their debts leading to the increase in loan portfolio quality (Jakubik, 2007). Garr (2013), by using unbalanced panel data set from 33 commercial banks covering the period from 1990 to 2010, suggests that credit risk in Ghana is significantly influenced by management efficiency, GDP per capita, government borrowing and the financial sector development, in which GDP per capita have a positive relationship. Besides, many other researches on credit risk proves the emperical impacts of economic growth (GDP) on credit risk, as Lowe (2002), Koopman and Lucas (2005).

Inflation is another macroeconomic variable which affects credit risk. Casto (2013) in his research concludes that inflation has positive effects on credit risk. When inflation increases, though the real interest rate of the borrower decreases, their real income decrease, leading to the deteriation of the borrower's capacity to pay their debt, which increase the credit risk for banks. High inflation rates also ask the borrowers to pay more for their essential commodities, which negatively affects credit risk (Mkukwana, 2013).

Interest rate is the price of borrowing, which affects credit risk via debt burden. The rising interest rate, followed by the increase in debt burden, leads to a higher rate of nonperforming loan. Research of Poudel (2013) concludes that interest rate has positive effects on credit risk in banks.

Exchange rate has great impacts on foreign trade of an economy, the exchange rate fluctuation is one of the main source of economic growth and economic stability (Zameer \& Siddiqi, 2010). Bozovic, Urosevic and Zivkovic 
(2009) suggest that the appreciation of foreign currencies against the local currency directly increase the cost of foreign currency borrowings which increase the debt burdens of the borrowers and increase the credit risk as a result. Hoggarth et al. (2005) analyzes the impacts of exchange rate via inflation and nominal interest rate and finds out that when foreign currency appreciates against the local currency, importing cost increases, inflation increases which burdens the borrowers and increases credit risk. The same relationship between exchange rate and credit risk is also found by Wong et al. (2010), Vogiazas and Nikolaidou (2011).

\subsubsection{Macroeconomic variables estimation model}

In order to estimate the relationship among macroeconomic variables and to make forecast about trends next time in Vietnam, the authors apply Vector Auto Regression model (VAR). Four variables including RGDP (Real Gross Domestic Product), INF (inflation rate), ITR (lending rate) and REER (Real effective exchange rate) are employed in the VAR model. All the data of four variables which are collected quarterly from statistical reports of Vietnam General Statistics Office, the State Bank of Vietnam and International Financial Statistics (IFS) of International Monetary Fund (IMF) during the period from 1994 to 2015. Since VAR model employs time-series data, the Unit Root Test (Table 1) and the Lag Length Criteria Test (Table 2) need to be conducted to assure the stationary of macro variables and appropriate lag for the model.

Table 1. Result from the Augmented Dickey-Fuller Test

\begin{tabular}{ccc}
\hline Variables & $\mathrm{Z}(\mathrm{t})$ & MacKinnon P-value \\
\hline DRGDP & -3.358 & 0.0125 \\
INF & -2.811 & 0.0568 \\
ITR & -2.571 & 0.0992 \\
DREER & -3.351 & 0.0127 \\
\hline
\end{tabular}

Table 2. Lag Length Criteria Tests

\begin{tabular}{cccc}
\hline Lag & LR & Df & P \\
\hline 0 & & & \\
1 & 35.904 & 16 & 0.003 \\
2 & $36.114^{*}$ & 16 & 0.003 \\
\hline
\end{tabular}

Table 3. Result from VAR Model

\begin{tabular}{ccccc}
\hline & DRGDP & INF & ITR & DREER \\
\hline \multirow{2}{*}{ DRGDP(-1) } & $-0.5563^{*}$ & $4.355911^{* *}$ & $1.875637^{* * *}$ & $3.924489^{* *}$ \\
& $(0.3151445)$ & $(1.880836)$ & $(0.7086509)$ & $(1.837763)$ \\
DRGDP(-2) & -0.36064 & 1.7094 & 0.1500969 & $2.301767^{*}$ \\
& $(0.2222172)$ & $(1.32623)$ & $(0.4996895)$ & $(1.295858)$ \\
INF(-1) & -0.0657 & 0.6472 & 0.139387 & 0.85045 \\
& $(0.1090527)$ & $(0.6508454)$ & $(0.2452218)$ & $(0.6359401)$ \\
INF(-2) & 0.093725 & -0.1684 & -0.0749611 & -0.077168 \\
& $(0.0679352)$ & $(0.405449)$ & $(0.1527628)$ & $(0.3961637)$ \\
ITR(-1) & -0.1076144 & -0.09727 & 0.49069 & -1.0063 \\
& $(0.2218677)$ & $(1.324144)$ & $(0.4989035)$ & $(1.293819)$ \\
ITR(-2) & -0.1816714 & $-0.09098 * *$ & 0.063388 & $1.873149^{*}$ \\
& $(0.1782064)$ & $(1.063566)$ & $(0.4007245)$ & $(1.039209)$ \\
DREER(-1) & $-0.0499399^{* *}$ & -0.0288288 & -0.038211 & -0.0807029 \\
& $(0.0424004)$ & $(0.2530528)$ & $(0.0953438)$ & $(0.2472575)$ \\
DREER(-2) & -0.0817668 & 0.8533749 & $0.3836483^{* *}$ & 0.2336139 \\
& $(0.0592987)$ & $(0.3539045)$ & $(0.1333421)$ & $(0.3457996)$ \\
C & 0.031167 & 0.05944 & $0.0472061^{*}$ & $-0.1475426^{* *}$ \\
& $(0.0126742)$ & $(0.075642)$ & $(0.0285)$ & $(0.0739097)$ \\
\hline
\end{tabular}

Note. ${ }^{*}, * * * * *$ : the significance level at $10 \%, 5 \%$ and $1 \%$ respectively

Table 3 and Figure 2 indicate that real GDP mostly unaffected by other macroeconomic variables whereas this indicator has strong influence on others. In contrast, the inflation rate has a minor impact on interest rate and real exchange rate but is affected relatively by other variables. Meanwhile, real exchange rate is relatively sensitive to the changes in macroeconomic conditions whereas interest rate nearly has no response to these changes. Through empirical analysis, it is concluded that real GDP is the most important variable which has significant impacts on the remaining variables in the model. 


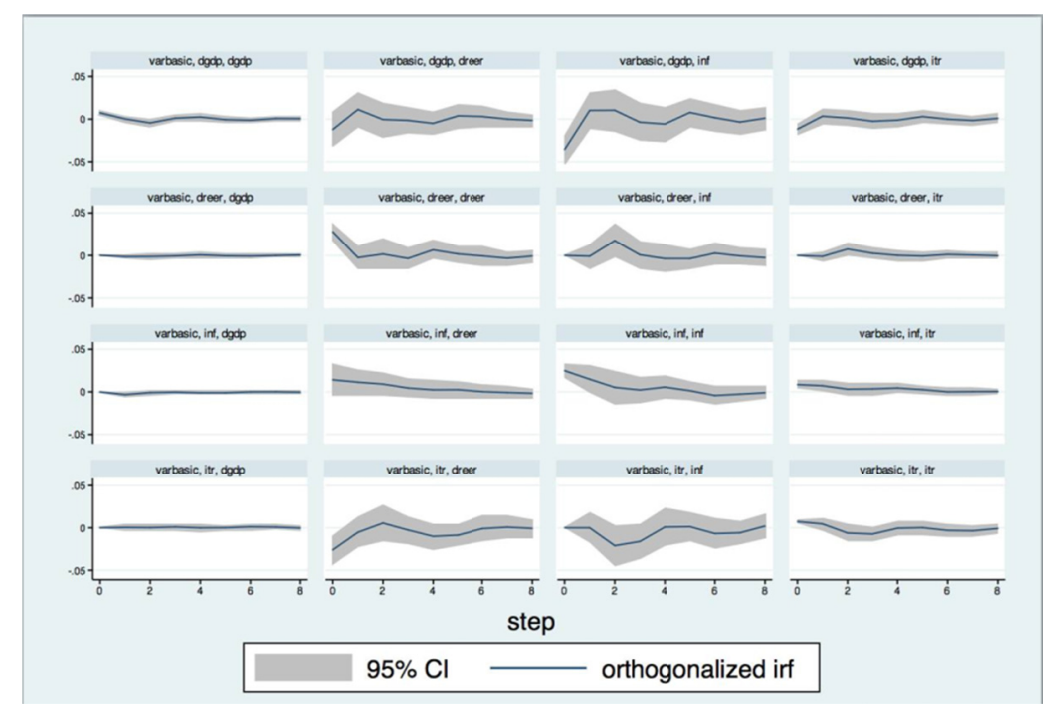

Figure 2. Response of Variables in VAR model

\subsubsection{Macroeconomic scenarios establishment}

Based on the results of VAR model in section 1, real GDP growth rate is demonstrated as the main factor which has major impacts on others. Moreover, since real GDP is one of the most important macroeconomic indicators which measures national well-being and simultaneously has strong interaction with other macro variables, we decide to choose the real GDP shock and build up different scenarios depending on the changes in this variable.

Table 4. GDP Growth Rate Forecast in 2016

\begin{tabular}{cc}
\hline Vietnam's Government & $6.7 \%$ \\
\hline World Bank & $6.6 \%$ \\
National Financial Supervisory Commission & $6.7 \%-6.8 \%$ \\
Central Institute for Economic Management & $6.82 \%$ \\
Standard Chartered Bank & $6.9 \%$ \\
\hline
\end{tabular}

Table 4 shows that all organizations have expected that Vietnam will achieve GDP growth rate of $6.7 \%$ to $6.9 \%$. Our target, however, is to examine the level of stress that commercial banks can suffer from the adverse economic conditions. Therefore, the adverse scenarios should be rebuilt. The authors determine to establish three scenarios of GDP shock (Note 1) based on time series data for 22 years (from 1994 to 2015).

Severe Scenario: this scenario has probability of 1 occurring in every 50 years. In other word, its value is below which $1 / 50=2 \%$ of the observations may be found.

Medium Scenario: this scenario has probability of 1 occurring in every 25 years. In other word, its value is below which $1 / 25=4 \%$ of the observations may be found

Mild Scenario: this scenario has probability of 1 occurring in every 10 years. In other word, its value is below which $1 / 10=10 \%$ of the observations may be found

Table 5. Result of RGDP Shocks by Using Different Methods

\begin{tabular}{cccc}
\hline & Severe scenario & Medium scenario & Mild scenario \\
\hline Method 1 & $4.97 \%$ & $5.17 \%$ & $5.43 \%$ \\
Method 2 & $4.22 \%$ & $4.64 \%$ & $5.28 \%$ \\
Method 3 & $4.20 \%$ & $4.50 \%$ & $5.07 \%$ \\
Method 4 & $4.12 \%$ & $4.41 \%$ & $4.86 \%$ \\
Final scenario & $4.00 \%$ & $4.50 \%$ & $5.00 \%$ \\
\hline
\end{tabular}

Based on data of RGDP named data set I, the authors calculated the values ranked at $2 \%, 4 \%$ and $10 \%$ by 4 methods:

Method 1: based on data set I, we chose $2^{\text {nd }}, 4^{\text {th }}$ and $10^{\text {th }}$ percentile through Percentile function.

Method 2: based on the assumption that data set I follows normal distribution, we computed medium value and standard deviation of RGDP which will be employed to calculate the $2^{\text {nd }}, 4^{\text {th }}$ and $10^{\text {th }}$ percentile.

Method 3: after eliminating trend factor in data set I, we had data set II which is the difference between data set I 
and trend factor. We chose $2^{\text {nd }}, 4^{\text {th }}$ and $10^{\text {th }}$ percentile in data set II, then converted them to growth rate value.

Method 4: based on data set II which is assumed normal distribution, we chose $2^{\text {nd }}, 4^{\text {th }}$ and $10^{\text {th }}$ percentile then converted them to growth rate value.

From the expected values of RGDP in different scenarios, the authors employ regression function which uses data of RGDP quarterly in the past and Goal Seek function in order to find forecasted value of RGDP quarterly in different scenarios. It is noted that the data must be calculated on quarterly basis in order to meet the requirement of the magnitude of data. The result of forecasted RGDP is shown in Figure 3.

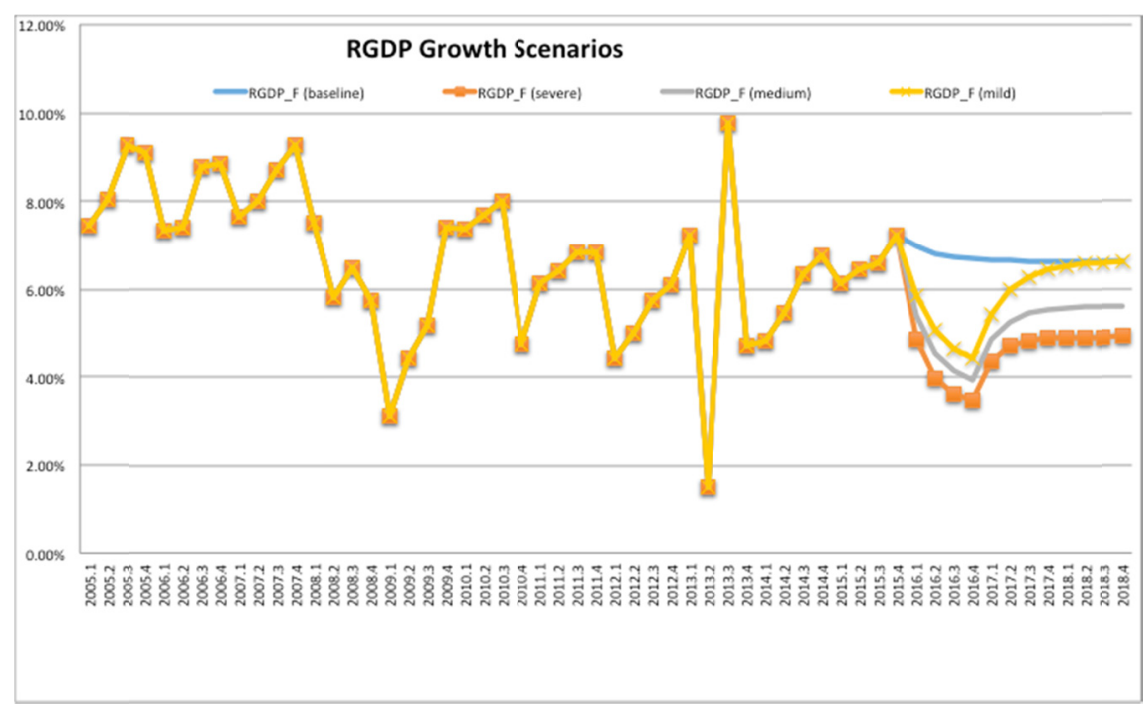

Figure 3. Forecast RGDP Growth Rate in 2016 (quarterly)

The figure illustrates the different degree of shock in 2016. Particularly, RGDP growth rate will decrease slowly from quarter to quarter. In fact, this movement of RGDP is appropriate since recession often becomes seriously by quarters. Therefore, we assumed that there is a RGDP shock in 2016, and the economy will recover quarter by quarter in 2017 and 2018.

Replacing forecasted RGDP growth rate in VAR model, we can estimate the value of inflation, lending rate and exchange rate in 2016 respectively.

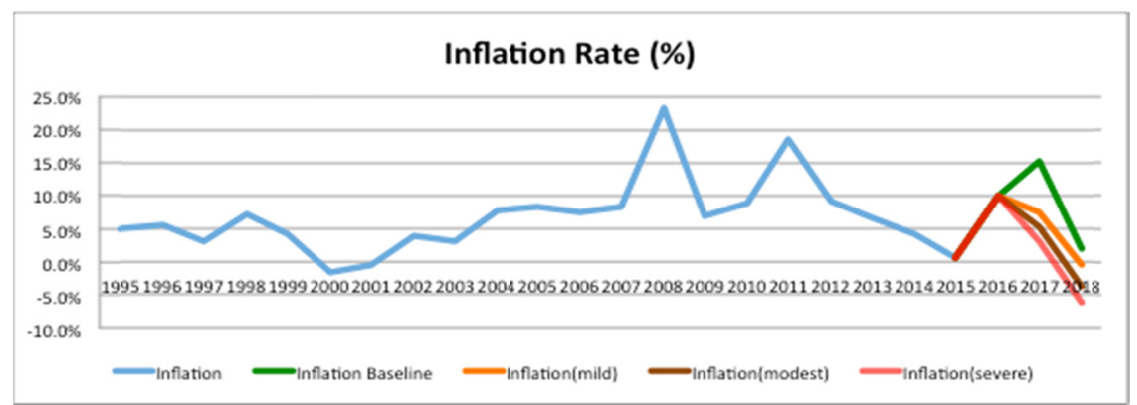

Figure 4. Forecast Inflation Rate in 2016

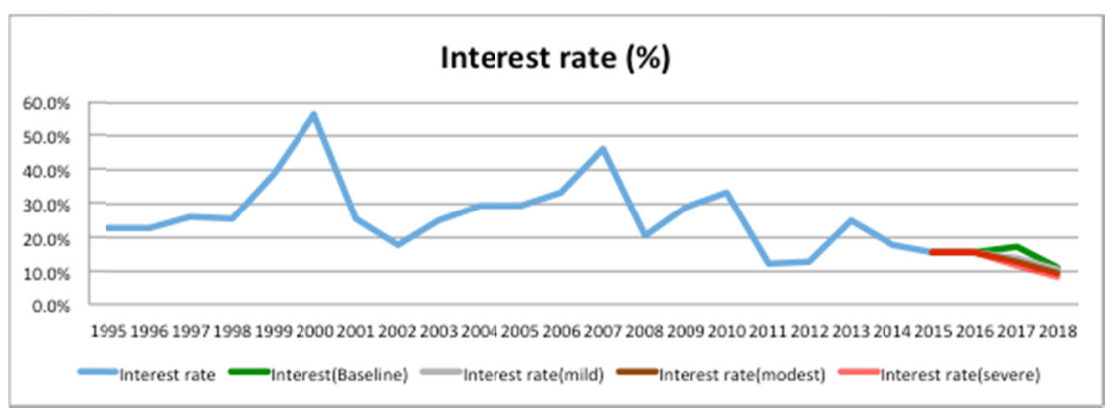

Figure 5. Forecast Interest Rate in 2016 


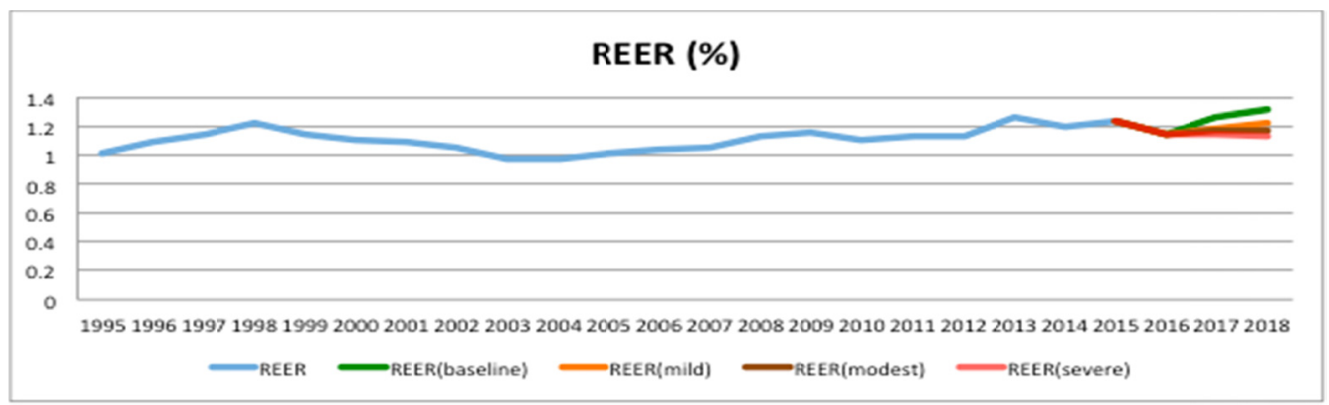

Figure 6. Forecast Real Effective Exchange Rate in 2016

\subsection{Estimation the Relationship between Nonperforming Loan Ratio and Macroeconomic Variables}

\subsubsection{Data and research model}

In this model, we use data which consists of nonperforming loans ratio and macro variables collected quarterly from 2008 to 2015. In particular, bad debt ratios of 10 commercial banks (have been account for $74.09 \%$ total assets of banking system) are collected from Bankscope of Bureau Van Dick, and are supplemented by Annual Reports published by banks. The data, however, is not fully reported by some commercial banks during the period of 2008 - 2015, therefore, we only generate unbalanced panel instead of balanced panel. In order to address some problems regarding heteroscedasticity and multicollinearity, the authors decide to employ Generalized Method of Moments - GMM which was created by Hansen (1982) and was developed by Arellano and Bond (1991). The regression equation is:

$$
\Delta N P L i, t=\propto_{0}+\propto_{1} \Delta N P L i, t-1+\propto_{2} \Delta R G D P t+\propto_{3} \Delta I N F+\propto_{4} \Delta I T R+\propto_{5} \Delta R E E R t+\left(\mu_{\mathrm{i}}, \vartheta i, t\right)
$$

This model uses lagged variables as well as differencing method. Based on the assumption that the first difference of instrument variables is not related to fixed effects, the model allows applying more instrument variables, hence, this helps to increase the effectiveness of the model.

\subsubsection{Variables}

\section{Dependent variables}

In previous studies in terms of Hoggarth, Sorensen and Zicchino (2005), Vazquez, Tabak and Souto (2012), Festic, Kavkler and Repina (2011) and Mannasoo and Mayes (2009), the nonperforming loan (NPL) ratio is considered as one of the most common indicator to measure the default rate of credit activities. The higher nonperforming loan ratio, the lower quality of debt and vice versa. Therefore, the authors decide to employ the ratio of NPL over gross loan as dependent variable in the model.

\section{Explanation variables}

Table 6. Summary of Independent Variables

\begin{tabular}{|c|c|c|c|c|}
\hline $\begin{array}{c}\text { Independent } \\
\text { variables }\end{array}$ & Name & Description & $\begin{array}{l}\text { Expected impact } \\
\text { on dependent } \\
\text { variables }\end{array}$ & Source \\
\hline $\begin{array}{l}\text { Real GDP } \\
\text { growth rate }\end{array}$ & RGDP & $\begin{array}{l}\text { An increase in real GDP leads to the rise real } \\
\text { income, helps to decrease unemployment rate, hence } \\
\text { supports repayment ability of borrowers. }\end{array}$ & - & $\begin{array}{l}\text { International } \\
\text { Monetary Fund }\end{array}$ \\
\hline Inflation rate & INF & $\begin{array}{c}\text { The higher level of inflation, the lower net value of } \\
\text { firms and individuals. Therefore, repayment ability } \\
\text { of borrowers will be affected negatively. }\end{array}$ & + & $\begin{array}{l}\text { General Statistics } \\
\text { Office of Vietnam }\end{array}$ \\
\hline $\begin{array}{l}\text { Real exchange } \\
\text { rate }\end{array}$ & REER & $\begin{array}{c}\text { An increase in real exchange rate means that national } \\
\text { competitiveness is improved. This helps to rise credit } \\
\text { quality in banking system in general. }\end{array}$ & - & $\begin{array}{l}\text { State Bank of } \\
\text { Vietnam }\end{array}$ \\
\hline Lending rate & ITR & $\begin{array}{l}\text { Increasing interest rates leads to rise financial burden } \\
\text { for borrowers, hence, nonperforming loan ratio. }\end{array}$ & + & $\begin{array}{l}\text { International } \\
\text { Monetary Fund }\end{array}$ \\
\hline
\end{tabular}

In studies regarding credit stress testing, many macroeconomic factors have been used as independent variables. According to Figlewski at el. (2012), there are three types of macroeconomic variables which affect the creditworthiness of a commercial bank as well as banking system, including: (i) factors showing general state of the economy (such as inflation rate, unemployment rate...); (ii) factors reflecting features of the economy (such 
as real GDP growth rate, commerce conditions...); (iii) factors reflecting financial market conditions (such as interest rate, rate of return on stock...)

Based on the reality of credit risk in the case of Vietnam, four factors including real GDP growth rate, CPI, real exchange rate and lending rate are taken into account to the model to conduct the credit stress testing.

\subsubsection{Results}

Table 7. Data Statistic Summary

\begin{tabular}{cccccc}
\hline Variables & Observations & Mean & Std. Dev & Minimum & Maximum \\
\hline NPL & 280 & 0.02 & 0.01 & 0.002 & 0.13 \\
RGDP & 320 & 0.06 & 0.02 & 0.015 & 0.10 \\
INF & 320 & 9.70 & 0.07 & 0.503 & 27.75 \\
ITR & 320 & 11.95 & 3.48 & 7.050 & 20.10 \\
REER & 320 & 1.16 & 0.05 & 1.058 & 1.23 \\
\hline
\end{tabular}

The results of model proved that the GMM model is proper determination. The coefficient of lagged dependent variable (NPLs) was significant at $1 \%$ showed that the level of adjustment to the balance point of dependent variable was relatively fast.

Table 8. Results of regression model

\begin{tabular}{|c|c|}
\hline \multicolumn{2}{|c|}{ Dependent Variable: NPL } \\
\hline Variables & Coefficient \\
\hline \multirow{2}{*}{ NPL $(-1)$} & $-0.3496062^{* * *}$ \\
\hline & (0.054 5349$)$ \\
\hline \multirow{2}{*}{ DRGDP } & $-0.0175693^{*}$ \\
\hline & $(0.0095896)$ \\
\hline \multirow{2}{*}{ INF } & 0.229721 \\
\hline & (0.019 606 8) \\
\hline \multirow{2}{*}{ ITR } & $0.000521^{* * *}$ \\
\hline & $(0.0001697)$ \\
\hline \multirow{2}{*}{ DREER } & $-0.0698406^{* * *}$ \\
\hline & $(0.0224661)$ \\
\hline \multirow{2}{*}{ Cons } & $-0.0088325^{* * *}$ \\
\hline & $(0.001574)$ \\
\hline
\end{tabular}

Note. ${ }^{*}, * * * * *$ : the significance level at $10 \%, 5 \%$ and $1 \%$ respectively

The regression result shows the positive relationship between nonperforming loan ratio and inflation and lending rate. This ratio and real GDP and real exchange rate are proved to be negatively related. Unfortunately, the coefficient of inflation rate variable is not significant.

\subsection{Stress Testing Credit Risk for Vietnamese Banks}

In order to assess capacity of bank to stand to given stressed events in banking business activities, the Capital adequacy ratio (CAR) which is often used as a proxy to determine the adequacy of banks' capital keeping in view their risk exposures. Banking regulators require a minimum capital adequacy ratio so as to provide the banks with a cushion to absorb losses before they become insolvent.

The research groups use CAR to assess the vulnerability of Vietnamese banks in stressed case. According to Circular No.36/2014/TT-NHNN issued by State bank of Vietnam, which applies to all Vietnamese banks, the CAR index is calculated as follow:

$$
C A R=\frac{\text { Own capital }}{\text { Risk Weighted Assets }} \times 100
$$

Based on the results of predicted changes in NPLs and others assumptions, the authors calculate banks' new capital adequacy ratios and compare them to regulatory minimum of $9 \%$ (according to circular No36) to determine how resilient are Vietnamese banks to adverse macro-financial shocks and in case the cushion- own capital- cannot protect the bank from potential credit risks then how much capital do the banks need to hold in the following year to ensure the regulatory minimum of $9 \%$ required by State bank of Vietnam. 


\subsubsection{Assumptions}

The new capital adequacy ratios of banks are calculated as following equation:

$$
C A R^{*}=\frac{\text { own Capital }-\Delta P}{R W A}
$$

- RWA: Risk-weighted assets

- $\triangle \mathrm{P}$ : Expected increase in loan loss provisions in response to an increase in non-performing loans. It is calculated as $\Delta P$ $=\triangle N P L s \times$ Loss given default. This formula means that the amount of the additional loan loss provisions that the bank is supposed to make will equal to the amount of the loans that it doesn't expect to recover.

Before estimating expected credit risks, the study bases on the following assumptions:

Firstly, Loss Given Default (LGD) is calculated as a percentage of losses to exposure at default. In other word, it reflects the percentage loss suffered by banks on a credit exposure if the borrowers default. According to Basel's figure, recovery as a percentage of exposure is either relatively high (around 70-80\%) or low (around 20-30\%). In the case of Vietnam, the authors assume that LGD of financial institutions is at $70 \%$.

Secondly, it is assumed that a bank's profit for the forecasted year equals zero, thus, own capital is not increased by the amount of profit.

Thirdly, in order to analyze the effects on CAR in different conditions, the study takes into account two cases of changes in RWA: (i) RWA remains stable, which aims to assess partly impact of adverse macroeconomic scenario on Vietnamese bank's CAR; (ii) RWA increases by $18 \%$ which is based on forecasted credit growth rate in 2016 being around $18-20 \%$. The purpose of this case is to assess the simultaneous effects of growth in RWA and adverse macroeconomic scenarios on Vietnamese bank's CAR.

\subsubsection{Results}

Based on empirical results of panel data regressions between NPLs and others macroeconomic variables under these above assumptions, the authors estimated the new CAR for 10 banks in 2 cases and 4 different scenarios.

Case I: Risk weighted assets remain stable.

Table 9. Estimated 2016 CAR* by Banks in Different Scenarios in Case of Unchanged RWA

\begin{tabular}{|c|c|c|c|c|c|c|c|c|c|}
\hline \multirow[b]{2}{*}{ No } & \multirow[b]{2}{*}{ Bank } & \multicolumn{2}{|c|}{ Baseline scenario } & \multicolumn{2}{|c|}{ Mild scenario } & \multicolumn{2}{|c|}{ Medium scenario } & \multicolumn{2}{|c|}{ Severe scenario } \\
\hline & & $\begin{array}{c}\text { CAR } 2015 \\
(\%)\end{array}$ & $\begin{array}{c}\text { CAR* } \\
(\%)\end{array}$ & $\begin{array}{c}\text { CAR } 2015 \\
(\%)\end{array}$ & $\begin{array}{c}\text { CAR* } \\
(\%)\end{array}$ & $\begin{array}{c}\text { CAR } 2015 \\
(\%)\end{array}$ & $\begin{array}{c}\text { CAR* } \\
(\%)\end{array}$ & $\begin{array}{c}\text { CAR } 2015 \\
(\%)\end{array}$ & $\begin{array}{c}\text { CAR* } \\
(\%)\end{array}$ \\
\hline 1 & Vietinbank & 9.64 & 9.76 & 9.64 & 9.68 & 9.64 & 9.64 & 9.64 & 9.57 \\
\hline 2 & BIDV & 9.01 & 9.18 & 9.01 & 9.00 & 9.01 & 8.96 & 9.01 & 8.87 \\
\hline 3 & Vietcombank & 10.01 & 10.15 & 10.01 & 10.03 & 10.01 & 9.99 & 10.01 & 9.92 \\
\hline 4 & Sacombank & 9.51 & 9.57 & 9.51 & 9.74 & 9.51 & 9.70 & 9.51 & 9.63 \\
\hline 5 & Eximbank & 16.29 & 16.46 & 16.29 & 16.24 & 16.29 & 16.20 & 16.29 & 16.12 \\
\hline 7 & VP Bank & 11.60 & 11.73 & 11.60 & 11.75 & 11.60 & 11.70 & 11.60 & 11.62 \\
\hline 8 & Techcombank & 12.35 & 12.48 & 12.35 & 12.29 & 12.35 & 12.26 & 12.35 & 12.20 \\
\hline 9 & Military Bank & 12.85 & 13.02 & 12.85 & 12.70 & 12.85 & 12.67 & 12.85 & 12.61 \\
\hline 11 & SHB & 11.38 & 11.56 & 11.38 & 11.40 & 11.38 & 11.34 & 11.38 & 11.25 \\
\hline 12 & Kienlong Bank & 16.62 & 16.82 & 16.62 & 16.55 & 16.62 & 16.50 & 16.62 & 16.42 \\
\hline
\end{tabular}

In this case, the empirical results show that in 3 adverse scenarios, most of banks' CAR witness a slightly decrease. To be more specific, there is only 1 (BIDV) out of 10 banks which has CAR being under $9 \%$ in modest and severe scenarios. Furthermore, the amount of capital that BIDV needs to be added in these two scenarios to ensure the regulatory minimum of $9 \%$ is not significant (being at $1.39 \%$ and $048 \%$ respectively, which are considerably less than the average own capital growth rate of banking system in the previous year)

The results show that when RWA is assumed to be increased by $18 \%$, in all 4 scenarios considered, the banks' CAR reduce significantly with 4 out of 10 banks (Vietinbank, BIDV, Vietcombank and Sacombank) having their forecasted CARs under the regulatory minimum of $9 \%$ according to Circular No36. BIDV is the bank which has lowest CAR among the others and in severe scenario, its CAR is estimated to be reduced to $7.31 \%$.

According to SBV, the banks with CAR being under regulatory minimum of $9 \%$ will be required to increase their capital. The authors estimated the amount of capital that 4 banks (Vietinbank, BIDV, Vietcombank and Sacombank) need to be added so that their CARs can ensure the minimum of $9 \%$. The amount of capital that 
need to increase of BIDV is highest (approximately 18-22\%\%) while the others' are at around 7-12\%. Comparing these figures with own capital growth rates in previous years, it can be concluded that BIDV is facing relatively high risks if they do not have appropriate plan to increase their own capital.

Table 10. The amount of capital needs to be added to ensure regulatory minimum CAR of $9 \%$ in Case of unchanged RWA

\begin{tabular}{|c|c|c|c|c|c|c|}
\hline \multirow{3}{*}{ No } & \multirow{3}{*}{ Bank } & \multirow{3}{*}{$\begin{array}{c}\text { Own Capital } \\
\text { (billion } \\
\text { dongs) }\end{array}$} & \multicolumn{4}{|c|}{ The amount of capital needs to be added } \\
\hline & & & \multicolumn{2}{|c|}{ Modest scenario } & \multicolumn{2}{|c|}{ Severe scenario } \\
\hline & & & Billion dongs & $\%$ & Billion dongs & $\%$ \\
\hline 1 & Vietinbank & 58391.2 & - & - & - & - \\
\hline 2 & BIDV & 50128.9 & 695.65 & $1.39 \%$ & 239.80 & $0.48 \%$ \\
\hline 3 & Vietcombank & 40837.5 & - & - & - & - \\
\hline 4 & Sacombank & 19149.1 & - & - & - & - \\
\hline 5 & Eximbank & 14529.2 & - & - & - & - \\
\hline 7 & VP Bank & 12194.7 & - & - & - & - \\
\hline 8 & Techcombank & 18924.9 & - & - & - & - \\
\hline 9 & Military Bank & 19621.8 & - & - & - & - \\
\hline 11 & SHB & 12203.1 & - & - & - & - \\
\hline 12 & Kienlong Bank & 2183.8 & - & - & - & - \\
\hline
\end{tabular}

Case II: RWA increases by 18\%

Table 11. Estimated 2016 CAR* by Banks in Different Scenarios When RWA increases by $18 \%$

\begin{tabular}{|c|c|c|c|c|c|c|c|c|c|}
\hline \multirow{3}{*}{ No } & \multirow{3}{*}{ Bank } & \multicolumn{2}{|c|}{ Baseline scenario } & \multicolumn{2}{|c|}{ Mild scenario } & \multicolumn{2}{|c|}{ Medium scenario } & \multicolumn{2}{|c|}{ Severe scenario } \\
\hline & & CAR & CAR* & CAR & \multirow{2}{*}{$\mathrm{CAR}^{*}(\%)$} & CAR & \multirow{2}{*}{$\mathrm{CAR}^{*}(\%)$} & CAR & CAR* \\
\hline & & $2015(\%)$ & $(\%)$ & $2015(\%)$ & & $2015(\%)$ & & $2015(\%)$ & $(\%)$ \\
\hline 1 & Vietinbank & 9.64 & 8.21 & 9.64 & 8.12 & 9.64 & 8.08 & 9.64 & 8.01 \\
\hline 2 & BIDV & 9.01 & 7.62 & 9.01 & 7.44 & 9.01 & 7.40 & 9.01 & 7.31 \\
\hline 3 & Vietcombank & 10.01 & 8.42 & 10.01 & 8.30 & 10.01 & 8.26 & 10.01 & 8.18 \\
\hline 4 & Sacombank & 9.51 & 7.94 & 9.51 & 8.11 & 9.51 & 8.07 & 9.51 & 8.00 \\
\hline 5 & Eximbank & 16.29 & 13.78 & 16.29 & 13.56 & 16.29 & 13.52 & 16.29 & 13.45 \\
\hline 6 & VP Bank & 11.60 & 9.64 & 11.60 & 9.66 & 11.60 & 9.61 & 11.60 & 9.53 \\
\hline 7 & Techcombank & 12.35 & 10.47 & 12.35 & 10.27 & 12.35 & 10.24 & 12.35 & 10.19 \\
\hline 8 & Military Bank & 12.85 & 10.93 & 12.85 & 10.61 & 12.85 & 10.57 & 12.85 & 10.51 \\
\hline 9 & SHB & 11.38 & 9.60 & 11.38 & 9.44 & 11.38 & 9.38 & 11.38 & 9.29 \\
\hline 10 & Kienlong Bank & 16.62 & 14.12 & 16.62 & 13.85 & 16.62 & 13.80 & 16.62 & 13.72 \\
\hline
\end{tabular}

Table 12. The amount of capital needs to be added to ensure regulatory minimum CAR of $9 \%$ when RWA increases by $18 \%$

\begin{tabular}{|c|c|c|c|c|c|c|c|c|c|c|}
\hline \multirow{3}{*}{ No } & \multirow{3}{*}{ Bank } & \multirow{3}{*}{$\begin{array}{c}\text { Own } \\
\text { Capital } \\
2015\end{array}$} & \multicolumn{8}{|c|}{ Capital needs to be added } \\
\hline & & & \multicolumn{2}{|c|}{ Baseline scenario } & \multicolumn{2}{|c|}{ Mild scenario } & \multicolumn{2}{|c|}{ Modest scenario } & \multicolumn{2}{|c|}{ Severe scenario } \\
\hline & & & $\begin{array}{l}\text { (Billion } \\
\text { dongs) }\end{array}$ & $(\%)$ & $\begin{array}{l}\text { (Billion } \\
\text { dongs) }\end{array}$ & $(\%)$ & $\begin{array}{l}\text { (Billion } \\
\text { dongs) }\end{array}$ & $(\%)$ & $\begin{array}{l}\text { (Billion } \\
\text { dongs) }\end{array}$ & $(\%)$ \\
\hline 1 & Vietinbank & 58391.2 & 5666.44 & 9.70 & 6284.85 & 10.76 & 6560.51 & 11.24 & 7055.69 & 12.08 \\
\hline 2 & BIDV & 50128.9 & 9036.61 & 18.03 & 10221.45 & 20.39 & 10528.05 & 21.00 & 11065.95 & 22.07 \\
\hline 3 & Vietcombank & 40837.5 & 2793.83 & 6.84 & 3386.71 & 8.29 & 3585.05 & 8.78 & 3924.46 & 9.61 \\
\hline 4 & Sacombank & 19149.1 & 2527.56 & 13.20 & 2113.83 & 11.04 & 2209.08 & 11.54 & 2373.31 & 12.39 \\
\hline 5 & Eximbank & 14529.2 & - & - & - & - & - & - & - & - \\
\hline 7 & VP Bank & 12194.7 & - & - & - & - & - & - & - & - \\
\hline 8 & Techcombank & 18924.9 & - & - & - & - & - & - & - & - \\
\hline 9 & Military Bank & 19621.8 & - & - & - & - & - & - & - & - \\
\hline 11 & SHB & 12203.1 & - & - & - & - & - & - & - & - \\
\hline 12 & Kienlong Bank & 2183.8 & - & - & - & - & - & - & - & - \\
\hline
\end{tabular}


In both two assumed cases, it is noticed that there is only a slight fluctuation in NPL ratio and even in severe scenario, banks' NPL ratio are still less than $3 \%$.

\section{Conclusion}

In order to assess credit risk tolerance in given macroeconomic stressed events, the study develops a methodology which consists of three main stages to conduct credit risk stress test for commercial banks in Vietnam against unfavorable macroeconomic scenarios. First, a relationship among macro variables (RGDP Real Gross Domestic Product, INF - inflation rate, ITR - lending rate of commercial banks, REER - Real exchange rate) was estimated through Vector Auto Regression (VAR) model, and based on this relationship, macroeconomic scenarios was set up in case there is any change in one of the variables. These scenarios include baseline, mild, modest and severe cases. Next, this study suggested a model which estimates the relationship between credit quality (expressed through nonperforming loan ratio) and the macro variables which are involved in first step. Simultaneously, through the change in bad debt ratio, the study assesses bank's ability to react against unfavorable macroeconomic shocks in the following year. Last, the new capital requirement ratio (CAR) will be recalculated, which is based on the increase in loan provision followed by the rise in nonperforming loan. With several assumptions, the new CAR of banks are calculated in two specific cases for the next year: (i) RWA remains unchanged and (ii) RWA grows by $18 \%$. In the first case, there are slight changes in the banks' CAR in which only BIDV's CAR falls under $9 \%$ in medium and severe scenarios. In the case that RWA increase by $18 \%$, the empirical results indicate that most of banks' CARs witnessed significant reductions in all of the scenarios. The estimated CARs of Vietcombank, BIDV, Vietinbank and Sacombank were being under regulatory minimum of $9 \%$ (according to Circular No36). Therefore, in order to achieve the credit growth rate of $18 \%$ and ensure the CAR of $9 \%$, it is advisable that the banks should have specific plans for increasing their own capital.

This paper has developed the stress test methodology for the Vietnamese banking system with regards to its credit risk. However, it is also subject to several limitations. First, it fails to take non-linearity between the variables of interest into account. Second, it doesn't distinguish between the boom-and-bust events (fails to consider the business cycle). Third, it disregards the feedback effects, which are infeasible to incorporate due to data restrictions.

Besides, although the study used a complex, multi-step approach to study the relationships between banking system's credit risk and macro-financial variables and to examine its resilience to adverse shocks, further exploration of relevant variables could improve the fit of the model; more bank-specific variables such as deposit-to-loan ratio or loan-to-GDP ratio could be added. Furthermore, the significant contribution to existing literature could be made by developing a model that accounts for feedback loops between banking system and real economy.

\section{References}

Arellano, M., \& Bond, S. (1991). Some tests of specification for panel data: Monte Carlo evidence and an application to employment equations. The Rev. of Eco. Stu., 58(2), 277-297. https://doi.org/10.2307/2297968

Bank of Japan. (2007). The Framework for Macro Stress-Testing of credit risk: incorporating Transition in borrower classification. Financial Systerm report.

Basel. (2009). Principles for sound stress test practices and supervison. Bank for International settlment.

Blaschke, W., Jones, M. T., Majnoni, G., \& Martinez Peria, M. S. (2001). Stress Testing of Financial Systems: An Overview of Issues, Methodologies, and FSAP Experiences. IMF Working Paper No. 88. http://dx.doi.org/10.5089/9781451851168.001

Boss M. (2002). A macroeconomic credit risk model for stress testing the Austrian credit portfolio. OeNB, Financial Stability Report, 4, 64-82.

Castren, O. S. (2008). Global Macro-financial Shocks and Expected Default Frequencies in the Euro Area. ECB Working Paper No. 875.

Castro, V. (2013). Macroeconomic determinants of the credit risk in the banking system: The case of the GIPSI. Econ.Model. 31, 672-683. http://dx.doi.org/10.1016/j.econmod.2013.01.027.

Cihák, M. (2007). Introduction to Applied Stress Testing. International Monetary Fund Working Paper No. 59. http://dx.doi.org/10.5089/9781451866230.001

Festic, M., Kavkler, A., \& Repina, S. (2011). The Macroeconomic Sources of Systemic Risk in the Banking Sectors of Five New EU Member States. Journal of Banking \& Finance, 35(2), 310-322. http://dx.doi.org/10.1016/j.jbankfin.2010.08.007. 
Figlewski, S., Frydman, H. and Liang, W. (2012). Modeling the Effect of Macroeconomic Factors on Corporate Default and Credit Rating Transitions. International Review of Economics and Finance, 21, 87-105. http://dx.doi.org/10.1016/j.iref.2011.05.004

Foglia, A. (2009). Stress Testing Credit Risk: A Survey of authoririties' approaché. International Journal of Central Banking. http://dx.doi.org/10.2139/ssrn.1396243

Garr D. K. (2013) Determinants of credit risk in the banking industry of Ghana. Developing Country Studies, 3(11). https://dx.doi.org/10.2139/ssrn.2679100

Hansen, P. (1982). Large Sample Properties of Generalized Method of Moments Estimators. Econometrica, 50(4), 1029-1054. https://dx.doi.org/10.2307/1912775

Hoggarth, G., Sorensen, S., \& Zicchino, L. (2005). Stress tests of UK banks using a VAR approach. Bank of England. http://dx.doi.org/10.2139/ssrn.872693.

Jakubik P.. (2007). Macroeconomic Environment and Credit Risk. Czech Journal of Economics and Finance 57(1-2), p. 41-59.

Koopman, S.J. and A. Lucas. (2005). Business and Default Cycles for Credit Risk. Journal of Applied Econometrics, 20, 311-323. http://dx.doi.org/10.1002/jae.833

Lowe, P. (2002). Credit Risk Measurement and Procyclicality, Monetary and Economic Department. Bank for International Settlements.

Mannasoo, K., \& Mayes, D. (2009). Explaining Bank Distress in Eastern European Transition Economies. Journal of Banking \& Finance, 33(2), 244-253. http://dx.doi.org/10.1016/j.jbankfin.2008.07.016

Miguel A. Segoviano Basurto \& Padilla, P. (2006). Portfolio Credit Risk and Macroeconomic Shocks: Application to Stress Testing Under Data-Restricted Enviroments. International Monetary Fund.

Mkukwana, K. K. (2013). The impact of macroeconomic factors on the risk of default: the case of residential mortgages. Doctoral Dissertation.

Petr Jakubík and Christian Schmieder. (2008). Stress Testing Credit Risk: Comparison of the Czech Republic and Germany. FSI Award 2008 Winning Paper, BIS

Pilinko V., R. A. (2014). A Macro-financial Model for Credit Risk Stress testing: The case of Latvia.

Van den End, J. W., M. Hoeberichts, \& M. Tabba. (2006). Modelling Scenario Analysis and Macro Stress-Testing. De Neder-landsche Bank Working Paper No. 119.

Vazquez, F., Tabak, B. M., \& Souto, M. (2012). A Macro Stress Test Model of Credit Risk for the Brazilian Banking Sector. Journal of Financial Stability, 8, 69-83. http://dx.doi.org/10.1016/j.jfs.2011.05.002

Vogiazas S. D., \& Nikolaidou E. (2011). Credit risk determinants in the Bulgarian banking system and the Greek twin crises. MIBES, South East European Research Centre, 177-189.

Wong, J., Wong, T. C., \& Leung, P. (2010). Predicting banking distress in the EMEAP Economics. Journal of Financial Stability, 6, 169-179. http://dx.doi.org/10.1016/j.jfs.2010.01.001

Zameer, S., \& Siddiqi, M. W. (2010). The impact of Export, FDI and External Debt on Exchange Rate Volatility in Pakistan. International Journal of Contemporary Research in Business, 2(7), 337-354.

\section{Note}

Note 1. We applied the implication which is suggested by the BRASS program - Banking Regulation and Supervision Support Project to determine the magnitude of GDP shock.

\section{Copyrights}

Copyright for this article is retained by the author(s), with first publication rights granted to the journal.

This is an open-access article distributed under the terms and conditions of the Creative Commons Attribution license (http://creativecommons.org/licenses/by/4.0/). 